九州大学学術情報リポジトリ

Kyushu University Institutional Repository

\title{
Mechanical Behavior of Separated Earlywood and Latewood of Douglas-Fir Using Digital Image Correlation Method
}

Kang, Chun-Won

Department of Housing Environmental Design, and Research Institute of Human Ecology, College of Human Ecology, Chonbuk National University

Schwarzkope, Mat thew

Department of Wood Science and Engineering, College of Forestry, Oregon State University

Muszynski, Lech

Department of Wood Science and Engineering, College of Forestry, Oregon State University

Jin, Taiquan

Department of Housing Environmental Design, and Research Institute of Human Ecology, College of Human Ecology, Chonbuk National University

他

https://doi.org/10.5109/1434401

出版情報：九州大学大学院農学研究院紀要. 59 (1)，pp. 127-131，2014-02-28. Faculty of Agriculture, Kyushu University

バージョン :

権利関係 : 


\title{
Mechanical Behavior of Separated Earlywood and Latewood of Douglas-Fir Using Digital Image Correlation Method
}

\section{Chun-Won KANG ${ }^{*}$, Matthew SCHWARZKOPF ${ }^{2}$ Lech MUSZYNSKI $^{2}$, Taiquan JIN $^{1}$, Hee-Jun PARK ${ }^{1}$, Ho-Yang KANG ${ }^{3}$ and Junji MATSUMURA ${ }^{4}$}

\author{
Laboratory of Wood Science, Division of Sustainable Bioresources Science, \\ Department of Agro-environmental Sciences, Faculty of Agriculture, \\ Kyushu University, Fukuoka 812-8581, Japan \\ (Received October 31, 2013 and accepted November 19, 2013)
}

\begin{abstract}
To clarify the mechanical behaviour differences between earlywood and latewood, separated the earlywood and the latewood specimens loaded to the rupture with tensile load parallel to the grain. The separated test specimens for tensile test were prepared from douglas fir (Pseudotsuga menziesii) and stress-strain relation was evaluated by optical measurement system using the Digital Image Correlation (DIC), which can visualize strain during the tensile test. The results are summarized as follows:

The estimated strain data by universal testing machine show good accordance with that estimated by DIC.

There was a difference in the fracture pattern of the earlywood and the latewood of douglas fir that the surface of ruptured earlywood typically simple while that of was somewhat complicate.

The longitudinal tensile strength of earlywood specimens of douglas fir at wood height from ground $12.8 \mathrm{~m}, 9.8 \mathrm{~m}, 6.7 \mathrm{~m}$ and $0.9 \mathrm{~m}$ were $51 \mathrm{MPa}, 69 \mathrm{MPa}, 110 \mathrm{MPa}$ and $114 \mathrm{MPa}$, while those of latewood were $208 \mathrm{MPa}, 234 \mathrm{MPa}, 247 \mathrm{MPa}$ and $198 \mathrm{MPa}$. Elastic modulus in the longitudinal tensile of earlywood specimens of douglas fir at wood height from ground $12.8 \mathrm{~m}, 9.8 \mathrm{~m}, 6.7 \mathrm{~m}$ and $0.9 \mathrm{~m}$ were $5458 \mathrm{MPa}, 7202 \mathrm{MPa}$, $9705 \mathrm{MPa}$ and $8761 \mathrm{MPa}$, while those of latewood were $13747 \mathrm{MPa}, 19405 \mathrm{MPa}, 17365 \mathrm{MPa}$ and $14044 \mathrm{MPa}$.
\end{abstract}

Key words: separated earlywood and the latewood, tensile test, optical measurement, DIC (digital image correlation) system

\section{INTRODUCTION}

Wood is an anisotropic and inhomogeneous material, a natural composite of complex hierarchical structure. Mechanical and physical characteristics of wood are dramatically different along its principal anatomical directions and just on the mezzo-scale of its anatomical structure, remarkable differences exist between heartwood and sapwood, earlywood and the latewood, mature wood and juvenile wood.

Continuous increase in computing power and sophistication of modeling software makes it possible to reflect this complexity in models used to solve problems in processing, design and construction of new engineered composites. However, the efficiency of the models depends on reliable as the input characteristics of the component materials.

This study is focused on the mechanical characteristics differences between the earlywood and the late-

\footnotetext{
1 Department of Housing Environmental Design, and Research Institute of Human Ecology, College of Human Ecology, Chonbuk National University, Jeonju 561-756, Korea

2 Department of Wood Science and Engineering, College of Forestry, Oregon State University, Corvallis, OR 97331, USA

Department of Biobased Materials, College of Agriculture and Life Sciences, Chungnam National University, Daejeon 305764 , Korea

${ }^{4}$ Laboratory of Wood Science, Division of Sustainable Bioresources Science, Department of Agro-environmental Sciences, Faculty of Agriculture, Kyushu University, Fukuoka 812-8581, Japan

* Corresponding author (E-mail: kcwon@jbnu.ac.kr)
}

wood. These differences have been recognized and studied for long time (e.g. Raczkowski, 1963: Bach L, 1973: Kitahara et al., 1981: Kitahara et al., 1984: Kitahara, 2008).

Alternative arrangement on radial direction by these earlywood and the latewood make annual ring and inherent pattern and affect the mechanical behavior of wood. The mechanical properties of earlywood and the latewood are affected by the cell wall characteristics. The latewood those formed in late of season is stronger than the earlywood, while those formed first in the season because the cells of latewood are thick-walled and with small cell cavities, while the earlywood have thin walls and large cell cavities as a microscopic level. These anatomical and mechanical differences between earlywood and the latewood cause many inhomogeneous properties of wood.

Kitahara (2008) reported that not only the latewood was stronger than the earlywood, but also the stressstrain relation in earlywood tends to be non-linear as opposed to straight linear relation in latewood.

One methodological challenge faced by researchers testing small specimens is reliable and artifact free measurement of deformations where the physical access to the specimen is very limited. Kitahara estimated the stress-strain relation by the separately attached thin strain gauge on the earlywood and latewood which might had influenced each other on the mechanical behavior.

To avoid the influence within earlywood and latewood, Kang et al. (2001) separated earlywood and latewood from Japanese cedar wood. Then they made each 
earlywood and latewood laminated sample specimens and estimated compression strength. They reported that the ultimate compressive stress (UTS) in laminated latewood specimen of Japanese cedar wood was four times higher than that of earlywood, and the earlywood reached to rupture instantaneously while the latewood reached to rupture as several step with the stress increasing. They concluded that the uniform cell wall ratio upon annual ring on earlywood cause instantaneous rupture and the cell wall ratio variation at on annual ring of latewood cause stepwise rupture.

These challenges may be efficiently addressed using non-contact optical methods based on Digital Image Correlation (DIC). In these methods, the surface displacements and strains in the specimens are calculated from series of successive images taken during the test and compared with the reference image of an undeformed state. The DIC technique employed by the VIC-3D software essentially calculates the gray scale intensity distribution for small subsets across the surface of the specimen. As the specimen is deformed the software uses a matching routine to correlate the deformed specimen to a reference (unloaded) specimen. From this correlation the displacement vectors and the components of the strain tensor can be calculated for the surface being imaged. This technique may offer stress-strain relation on the separated earlywood and latewood with no contact on the both direction of parallel and vertical to loading direction while the conventional methods such as strain gauge or extensometer can estimate only the loading direction. The measurements can then be visualized as color-coded displacement and strain maps. This technology has been used since the late 1980s to investigate the displacement of material loaded under stress (Ranson et al., 1987; Bruck et al., 1989; Vendroux and Knauss, 1998). Optical measurement techniques have been successfully used for measurement of deformations and strain in wood specimens during wood drying (Schmidt, 2002: Muszyński, 2006; Muszyński et al., 2006) and used for the microscopic observation of swelling behavior of wood cell wall with moisture absorption (Murata and Masuda, 2001, 2006).

The overall goal of this research was to improve the understanding of the micromechanics on the mesoscale, which is needed in for accurate modeling of the many wood-based materials such as plywood. The specific objective of this study was to determine and compare the longitudinal mechanical characteristics of small latewood and earlywood samples of Douglas fir. The strains were measured using optical measurement system based on DIC principle.

\section{MATERIALS AND METHODS}

In this study, to estimate the differences in mechanical characteristics of earlywood and latewood, earlywood and latewood samples were separated from Douglas-fir wood block and subjected to destructive tensile tests in longitudinal direction. The strain-stress characteristics were determined from the load record obtained from the universal testing machine load cell and mean strain measured on the sample surface using optical measurement unit.

\section{Materials and specimens fabrication}

The material for this study was obtained from one Douglas fir tree from Newport, Oregon estimated to be 40 years old. Four $50.4 \mathrm{~mm}$ thick disks were cut from four locations along the trunk of the tree: at $0.91 \mathrm{~m}$, $6.71 \mathrm{~m}, 9.75 \mathrm{~m}$ and $12.80 \mathrm{~m} \mathrm{(} 3 \mathrm{ft}, 22 \mathrm{ft}, 32 \mathrm{ft}$ and $42 \mathrm{ft}$ ) from root collar. The disks were then conditioned at $20^{\circ} \mathrm{C}, 65 \% \mathrm{RH}$ for a minimum 2 months. From these disks, small clear specimens of earlywood and latewood were prepared with nominal dimensions of $3 \mathrm{~mm} \times 1 \mathrm{~mm}$ $\times 30 \mathrm{~mm}$ (radial $\times$ tangential $\times$ longitudinal). The full set of specimens is shown in Figure 1. Juvenile wood which has wide annual ring was primarily used to get adequate sample volume for earlywood and latewood separation. These small separated earlywood and latewood specimens were cut into dog bone shaped test specimens by hand using a light router with sander bite. Cross sections dimensions of the specimen neck area were measured with a micrometer, to the nearest $0.001 \mathrm{~mm}$, at three locations along the neck. The ultimate tensile stress (UTS) for individual specimens was calculated using the smallest of the three measured cross sections of the neck area, while the elastic modules (E) were calculated using mean cross- section area for the specimen. The specimens were sprayed with a matte black paint on the surface to create a random speckle pattern to enhance the digital image correlation.

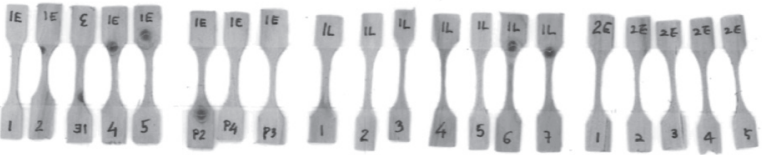
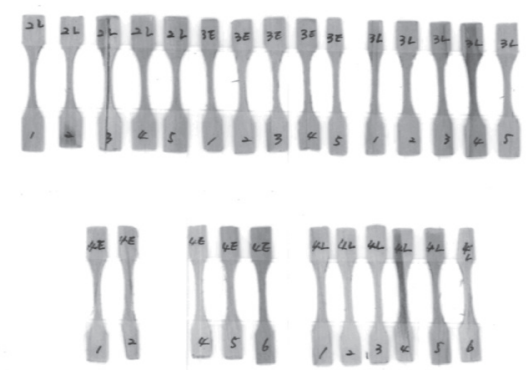

Fig. 1. Photograph of sample specimens.

\section{Experimental apparatus}

The measurement system consisted of a small-scale universal testing machine (Instron ElectroPuls E1000) with $\pm 2 \mathrm{kN}$ range load cell, and an optical measurement system, with microscopic lenses, a digital image acquisition board and VIC3D digital image correlation software by Correlated Solutions, Inc. The tests were performed in displacement control at ramp rate of $2 \mathrm{~mm} /$ minute. Digital images of the specimen were sampled every $2 \mathrm{~s}$. 
The repeatability of the load measurement was below $\pm 1 \mathrm{~N}$.

The stress-strain characteristics were determined from the load record obtained from the universal testing machine load cell synchronized with the image acquisition schedule, and from mean strain measured on the images of the specimen longitudinal-tangential surface during the test.

The ultimate tensile stress (UTS) was determined as the maximum registered load and smallest crosssection measured in the neck area of each specimen. The elastic modulus (E) was determined as a slope of a straight-line fitted to the stress-strain curve between $20 \%-50 \%$ of the maximum stress.

\section{RESULTS AND DISCUSSION}

\section{Stress-strain relation in earlywood and latewood specimens}

The strain on a tangential-longitudinal surface of wood can be visualized by DIC.

In the view of strain development estimation by DIC, strain developments of separated earlywood and latewood specimens visualized by DIC. Figure 2 and 3 show the stress-strain relation between the separated earlywood and latewood on tensile stress. These figures summarized as 6 steps during whole test. From these figures, strain development by the stress until rupture can be achieved.

From those DIC figures, additional analysis of strain-stress relation of the separated earlywood and latewood on the direction of parallel and vertical to load-
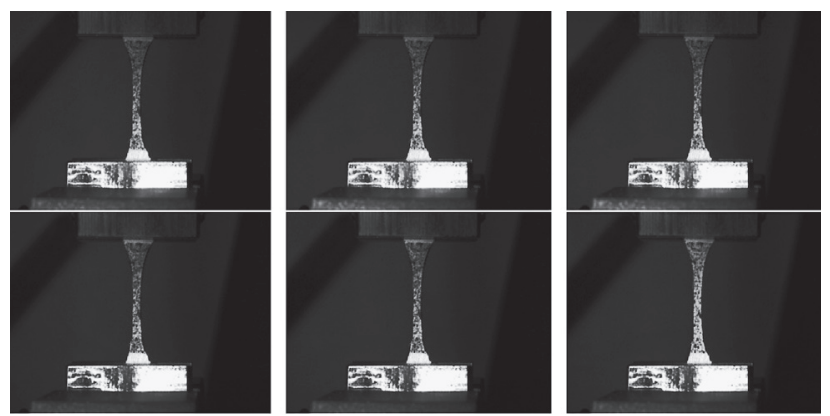

Fig. 2. Photograph of strain development by the DIC on the separated earlywood.
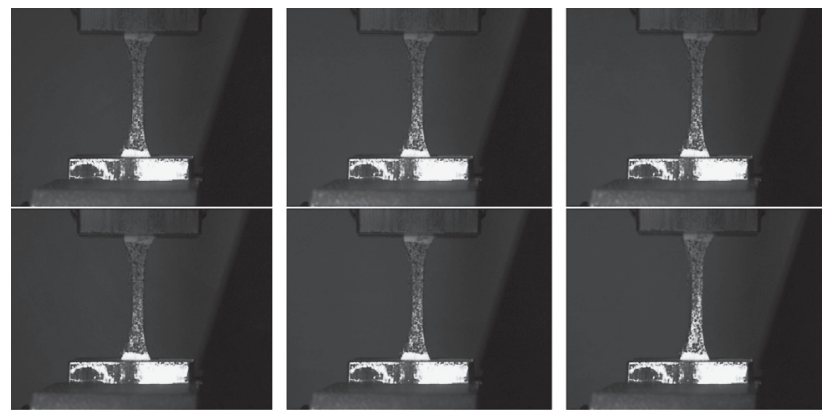

Fig. 3. Photograph of strain development by the DIC on the separated latewood. ing direction can be estimated as shown in figure 4 and figure 5. In figures, boxes on the curves at the UTS represent the point at which the image to the right was taken. The strain plotted on the graph is the mean strain value for the entire colored area on the specimen to the right. These figures show the typical stress-strain diagram of separated earlywood and latewood specimens, and parallel and vertical strains. These DIC picture matched stress-strain diagram figures were got at the loading level of approximate $80 \%$ of ultimate strength. The red graphs represent the vertical strain to the loading and the blue graphs represent parallel strain of the sample specimen. Also, + means lengthening and means shortening from original length. The stressstrain relation on the direction of parallel to the loading of separated earlywood shows weaker than that of latewood specimens and the inclination show slower than that of latewood. Also, the slope of vertical direction to the loading of separated earlywood was slower than that of latewood. This means that the latewood performs the function of mechanical support against the load much more than the earlywood.

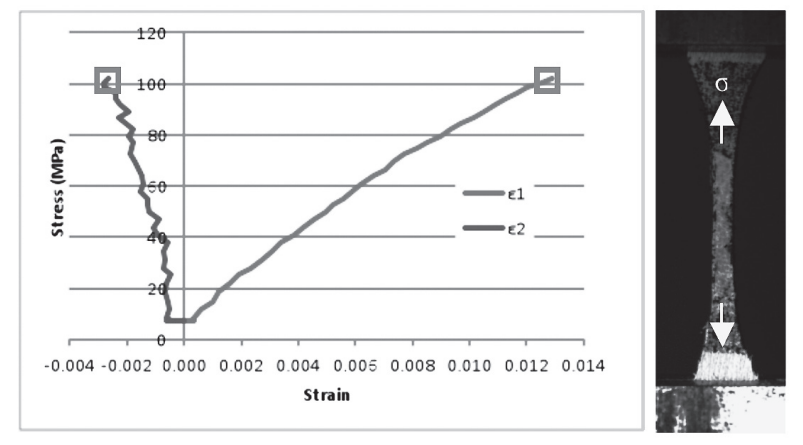

Fig. 4. Stress-strain diagram of specimen $3 \mathrm{E} 1$ showing the major and minor principal strains.

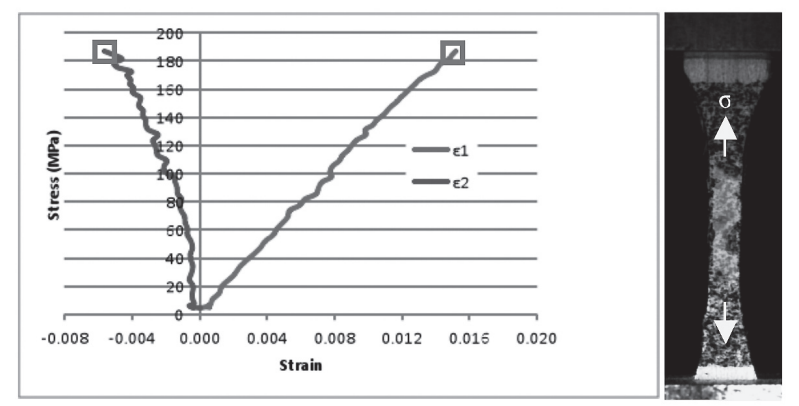

Fig. 5. Stress-strain diagram of specimen $3 \mathrm{~L} 1$ showing the major and minor principal strains.

In addition, there were no significant differences between the earlywood and latewood on the ratios of vertical strain to parallel strain.

Figure 6 shows the fracture pattern differences between the earlywood and latewood. In figure, the cross section of broken specimen is relatively simple, while that of latewood specimens show somewhat complicate. 
In the view of the fracture pattern difference between earlywood and latewood, Kang et al (2001) surmised that the uniform cell wall ratio upon annual ring on earlywood cause instantaneous rupture and the cell wall ratio variation at on annual ring of latewood cause stepwise rupture.

Tensile strength and modulus of elasticity of separated earlywood and latewood

Figure 7 shows the relationship of density and tensile strength of the separated earlywood and latewood of the douglas fir. From the Figure 7, the density and tensile strength of separated latewood was about 2-3 times higher than that of earlywood. The maximum tensile strength of latewood was about $320 \mathrm{MPa}$ with the density of $800 \mathrm{~kg} / \mathrm{m}^{3}$, and about $160 \mathrm{MPa}$ with the density of $660 \mathrm{~kg} / \mathrm{m}^{3}$ for earlywood.

On the view of elastic modulus in tensile differences between separated earlywood and latewood specimens, the elastic modulus of latewood higher than earlywood as shown in Figure 8. And the maximum value was about $20000 \mathrm{MPa}$ for latewood, which is 2 times for ear-
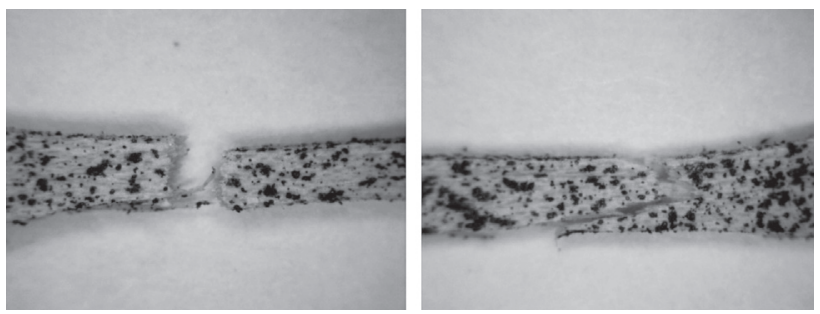

Fig. 6. Typical fracture pattern differences between the earlywood and latewood (left:earlywood, right:latewood).

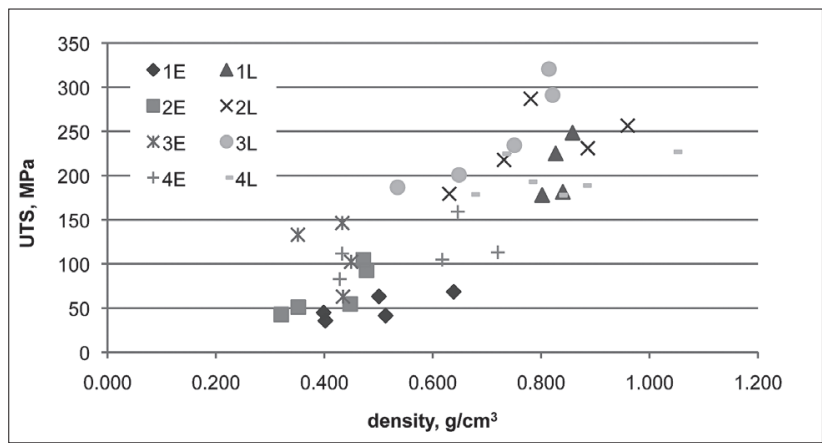

Fig. 7. Relationship between density and tensile strength of the separated earlywood and latewood.

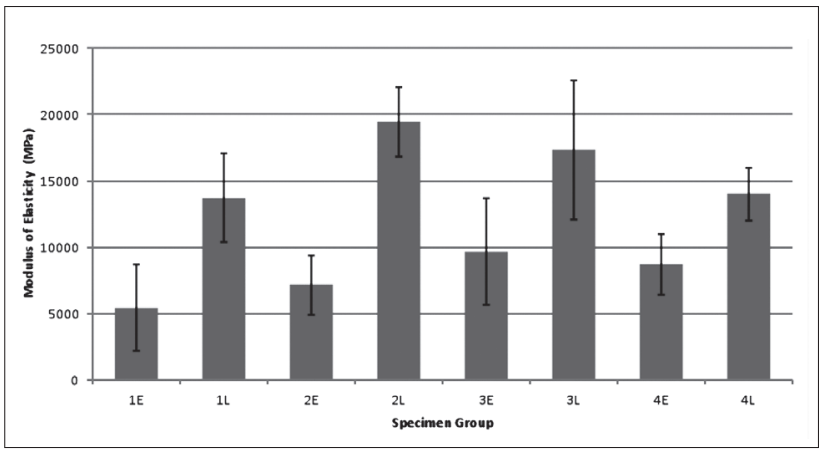

Fig. 8. MOE values of separated earlywood and latewood. lywood. From these results, it is apparent that the latewood performs the function of mechanical support against the load applied.

These values reported in this study may be slightly lower than other researchers have found for other softwood because this study primarily used the juvenile wood as shown in previous paragraph.

In the view of relation between wood height and mechanical properties, both of MOR and MOE increased with wood height and then decreased with height.

\section{CONCLUSIONS}

We investigated the mechanical behavior of separated earlywood and latewood specimens, using a new methodological approach which makes use of optical measurement techniques with a digital image correlation (DIC) system. The results are summarized as follows:

The strain development estimation of separated earlywood and latewood sample specimens by DIC was accurately and continuously observed by DIC and the strain estimated by DIC show good accordance with those estimated by load cell of universal testing machine.

The typical fracture pattern of earlywood specimens was simple while that of latewood specimens show somewhat complicate. This result lead us the further investigation for microscopic anatomical analyze of fracture pattern.

The mean value on tensile strength and elastic modulus of separated latewood was about 2-3 times higher than that of separated earlywood. It is apparent that the latewood performs the function of mechanical support against the load applied.

\section{ACKNOWLEDGEMENTS}

This paper was supported by the research funds of Chonbuk National University in 2011.

\section{REFERENCES}

Bruck, H. A., S. R. McNeill, M. A. Sutton and W. H. I. Peters 1989 Digital Image Correlation Using Newton-Raphson Method of Partial Differential Correction. Experimental Mechanics, 28(3): 261-267

Kang, C. W., J. Tsutsumi and S. Jang. 2001 Mechanical behavior of earlywood and latewood under longitudinal compression load. Mokchae Konghak, 29(2): 76-83 (In Korean)

Kang, H. Y., L. Muszyński and M. R. Milota. 2011a Optical Measurement of Deformations in Drying Lumber. Drying Technology, 29(2): 127-134

Kang, H. Y., L. Muszyński, M. R. Milota, C. W. Kang, J. Matsumura. 2011b Preliminary Optical Measurement of Non-uniform Drying Strains and Check Formation in Drying Wood. J. Fac. Agr., Kyushu Univ., 56(2): 313-316

Kitahara R., J. Tsutsumi and T. Matsumoto 1981 Observations on cell wall response and mechanical behaviour in wood subjected to repeated static bending load. Mokuzai Gakkaishi, 27: 1-7 
Kitahara R., J. Tsutsumi and T. Matsumoto 1984 Effect of static bending-load on the mechanical behaviour of wood. Mokuzai Gakkaishi, 30: 522-529

Murata K. and M. Masuda 2001 Observation of microscopic swelling behavior of the cell wall. J. Wood Sci., 47: 507-509

Murata K. and M. Masuda 2006 Microscopic observation of transverse swelling of latewood tracheid:effect of macroscopic/mesoscopic structure. J. Wood Sci., 52: 283-289

Muszyński, L. 2006 Empirical Data for Modeling: Methodological Aspects in Experimentation Involving Hygromechanical Characteristics of Wood. Drying Technology, 24(9): 11151120.

Muszyński, L., R. Lagana and S. M. Shaler 2006 Hygro-Mechanical Behavior of Red Spruce in Tension Parallel to the Grain. Wood and Fiber Science, 38(1): 155-165

Raczkowski, J. 1963 The toughness of early wood and late wood from Douglas fir of polish origin. Holzforschung, 17: 189-190

Ranson, W. F., M. A. Sutton and W. H. Peters 1987 Holographic and Specle Interferometry. In "SEM Handbook of Experimental Mechanics", ed. by A. S. Kobayashi, Englewood Cliffs, PrenticeHall, Inc., pp. 388-429

Schmidt, T., J. Tyson and K. Galanulis 2002 Full-Field Dynamic Displacement and Strain Measurement Using Advanced 3-D Image Correlation Photogrammetry. Part II. Experimental Techniques, 27(4): 44-47

Vendroux, G. and W. G. Knauss 1998 Submicron Deformation Field Measurements: Part 2. Improved Digital Image Correlation. Experimental Mechanics, 38(2): 86-92 